\title{
El Partido Comunista Revolucionario y la definición de una interpretación histórica en su período formativo (1967-1987)
}

\author{
The Revolutionary Communist Party and the definition \\ of a historical interpretation in its formative period (1967-1987)
}

\author{
Matias J. Rubio*
}

\begin{abstract}
Resumen: En este escrito realizamos un análisis de las primeras líneas de intervención historiográfica producidas por el Partido Comunista Revolucionario entre 1967 y 1987. Indagamos en las lecturas de la Historia Argentina efectuadas por el partido y sus intelectuales poniéndolas en relación con sus planteos políticos y programáticos. Abordamos la cuestión partiendo de desglosar las que entendemos como las puertas de entrada a la producción historiográfica: la historia de la izquierda, la cuestión agraria y el debate en torno al modo de producción dominante en América Latina.
\end{abstract}

Palabras clave: historiografía militante, izquierda, intelectuales, Partido Comunista Revolucionario

\begin{abstract}
In this paper we analyse the first historiographic interventions made by the Revolutionary Communist Party between 1967 and 1987. We inquire into the interpretations of Argentinian History made by the party and its intellectuals linking them with their political and programmatic poses. We approach the question by breaking down what we consider to be the gates into the historiographic production: the history of the left, the agrarian question and the debate on the dominat mode of production in Latin America.
\end{abstract}

Key words: militant historiography, left, intellectuals, Revolutionary Communist Party

Recibido: 12 abril 2018 Aceptado: 23 junio 2018

\footnotetext{
* Argentino, Profesor de Historia. Docente de Historiografía e investigador de la Universidad Nacional de Lujan. rubiomatias08@ hotmail.com.ar
} 


\section{Introducción}

En este trabajo proponemos un análisis de las intervenciones historiográficas desarrolladas por el Partido Comunista Revolucionario (PCR) entre 1967 y 1987, desde su fundación hasta su quinto congreso. De esta manera, establecemos un estudio introductorio sobre una tradición específica de la historiografía militante de las izquierdas de Argentina ${ }^{1}$ que no ha sido abordada sistemáticamente hasta el momento ${ }^{2}$.

Nuestro trabajo se centra en el análisis de las producciones de dicho partido en torno a la Historia Argentina, y busca establecer la relación de estas respecto de sus definiciones políticas y programáticas $^{3}$. En consecuencia, apuntamos a relevar, comprender y dimensionar el papel jugado por estas producciones en el proceso formativo del partido. El recorte temporal que realizamos es tributario de una hipótesis de trabajo que excede el presente escrito: en ella consideramos que, luego de su fundación y debido a la neutralización de la abierta lucha de tendencias en su seno en los primeros años de vida, el partido en cuestión inició un largo camino formativo hasta estabilizar su programa político ${ }^{4}$. Si bien carecemos aún de una historia del partido sobre la cual apoyarnos,

${ }^{1}$ La historiografía de las izquierdas se enmarca, junto con el revisionismo histórico, en lo que se ha dado en denominar como historiografías militantes. Lo especifico de esta forma de escribir la historia es su relación con la cuestión política; es decir, en estos casos la operación historiográfica es subordinada a la política mediata e inmediata. Por ello se ha afirmado que, en contraste con la historiografía académica, sus ritmos son diferentes ya que suele ser escrita, con frecuencia, para que se la consuma en el mismo momento de su producción. El desarrollo y las características de estas experiencias, dada la relevancia otorgada a la intervención política, se encuentran en estrecha relación con su contexto histórico, entendiendo este último como la forma que toma la intervención política, en un momento dado, por el actor/autor. Sobre esta área de estudios véase: Omar Acha, Historia critica de la historiografía argentina, Vol.1: Las izquierdas en el siglo XX, Buenos Aires, Prometeo, 2009; Fernando Devoto y Nora Pagano, Historia de la historiografía argentina, Buenos Aires, Sudamericana, 2009; Fernando Devoto, Nora Pagano y Eduardo Hourcade, La historiografía académica y la historiografía militante en Argentina y Uruguay, Buenos Aires, Biblos, 2004; Campione Daniel, Argentina la escritura de su Historia, Buenos Aires, Centro Cultural de la Cooperación, 2002.

2 Salvo por el tratamiento, de carácter general, realizado por Omar Acha, no contamos con ningún otro trabajo que aborde la cuestión. Allí el historiador argentino introduce, brevemente, la corriente como un desprendimiento, "la rebelión maoísta", de la historiografía que tiene su núcleo en el Partido Comunista de Argentina. Acha, op. cit., 195-201.

3 En este punto, consideramos primordial tomar como punto de partida analítico las observaciones realizadas por Omar Acha en relación a los vínculos entre historia y política. El historiador sostiene que "el análisis discursivo es insuficiente para captar el drama de la relación entre historia y deseo político. Lo interesante no es la 'construcción' del sentido de los relatos a través de retóricas o epistemes, sino la irreductible distancia entre las aspiraciones de cambio y las múltiples formas que la historia contada puede adoptar. Por lo tanto, se hace necesario aplicar una perspectiva materialista donde la escritura se encuentre permanentemente acosada por las exigencias de la praxis política. Y donde, por otra parte, se halle a destiempo de los apremios tácticos de la lucha. De allí que la pregunta por los contextos e intenciones político-ideológicas de las construcciones textuales sea legítima, e incluso imprescindible, para prácticas de la historia en las izquierdas que asumen desde el inicio una configuración que pretende derivaciones prácticas". Ibid, 18.

4 Consideramos que el PCR, en el periodo señalado, fue definiendo el carácter de la revolución en Argentina, identificando un enemigo principal, precisando el rol de la burguesía nacional y especificando el lugar ocupado por el problema de la lucha interimperialista en el escenario nacional. Asumimos, entonces, que en 1974 se estableció una matriz en cuanto a la definición del carácter de la revolución en Argentina y que, luego 
indagamos y exponemos sus principales aspectos, ya que la consideramos un elemento central para comprender en todas sus aristas sus producciones. Estas últimas, según nuestro juicio, se encontraron en una estrecha relación, conflictiva y/o armónica, con la línea política general de la organización.

En relación con el objetivo mencionado adoptamos una forma concreta de abordaje y exposición. Partimos de desglosar lo que entendemos como puertas de entrada a la producción historiográfica: temas relevantes, con una producción continuada, que guardan una relación directa con las posiciones políticas formuladas por la organización. Realizamos esta selección a partir de un relevamiento general del volumen y las dimensiones de las producciones partidarias durante el periodo señalado. En este sentido, operamos un recorte arbitrario que incluye los temas que, en nuestro criterio, nos permiten poner en tensión la construcción del programa y la identidad partidaria con la elaboración historiográfica realizada por la organización. Observamos, en los materiales partidarios, un primer momento de discusiones abiertas donde los temas seleccionados para este trabajo son protagonistas y, luego, un segundo momento donde estas discusiones son agotadas con la publicación de obras integrales, de cierta envergadura, donde los principales dirigentes sentaron la posición oficial al respecto. Por cuestiones de espacio, relegamos el contexto histórico en sentido amplio y nos referimos al mismo exclusivamente a través de las lecturas coyunturales realizadas por la organización. Consideramos que, en futuros trabajos, producto de la profundización de nuestro estudio, podremos dar cuenta de la relación de esta lectura particular del pasado con su contexto más general.

En primer lugar, abordamos los aspectos de la historia de la organización que terminaron por definir las estrategias partidarias. Luego establecemos una descripción y análisis de los primeros y principales temas tratados por el partido y sus intelectuales: la historia de la izquierda, el problema de las clases sociales en el mundo rural y, por último, el debate en torno al modo de producción dominante en América Latina. Estos últimos, como veremos, revistieron una nodal importancia tanto para las definiciones y discusiones programáticas internas, como para la futura producción de obras que el partido presentaría hacia afuera como portadoras de sus posiciones. Finalmente, realizamos un balance de lo analizado y expondremos las que consideramos hipótesis útiles para profundizar el estudio de esta expresión de la historiografía militante de las izquierdas.

\section{Partido Comunista Revolucionario: nacimiento, formación y teoría}

El PCR nació oficialmente en enero de 1968, producto de la expulsión de un grupo dirigente de la Federación Juvenil Comunista (FJC) y de un puñado de dirigentes del Partido Comunista (PC). Inmediatamente se incorporaron a la organización algunos

de la dictadura (período donde no hubo congresos partidarios), terminó de cimentarse, sin modificaciones sustanciales, su programa político. Sin embargo, como advertimos aquí, esta consideración forma parte de una hipótesis de trabajo, no agotada en este artículo, que debe ser puesta a prueba en la investigación que nos encontramos transitando. 
dirigentes del Movimiento Estudiantil Nacional de Acción Popular (MENAP). Luego, antes del primer congreso, se sumarían militantes de la Agrupación de Obreros Metalúrgicos-Felipe Vallese, entre los cuales se encontraba René Salamanca, y Eugenio Gastiazoro, proveniente del autodisuelto Movimiento de Liberación Nacional (MALENA) 5

El grupo expulsado del PC se constituyó, en un primer momento, bajo el nombre de Partido Comunista - Comité Nacional de Recuperación Revolucionaria (PC-CNRR). Esta fracción inicial arrastró aproximadamente cuatro mil militantes, la mayoría de ellos estudiantes, con muy escaso componente obrero ${ }^{6}$. A partir de ese momento, para determinar su futuro, la organización se sumergió en una discusión programática y estratégica que se prolongó hasta su $1^{\circ}$ Congreso en 1969. Para ese entonces, del número inicial de militantes solo quedaban setecientos en todo el país. Pese al escaso componente obrero inicial en sus filas, el partido experimentó una rápida inserción en el proletariado industrial. Este impulso se encontraba íntimamente relacionado con una resolución que adoptó la organización sobre su carácter político: constituirse como un partido de la clase obrera guiado por una estrategia de tipo insurreccional. En un primer momento, el grupo se identificó con el Che Guevara y la revolución cubana, identificación que expresaba cierta hibridación en cuanto a sus definiciones ideológicas. ${ }^{7}$

José Ratzer y Julio Godio8 fueron quienes escribieron, bajo los seudónimos de Fígari y Marín, los documentos programáticos aprobados por el $1^{\circ}$ y $2^{\circ}$ Congresos de la organización. Este dúo inicial, al mediar la década de los setenta, sería relevado de ese protagonismo por otros cuadros como Otto Vargas, Horacio Ciafardini, Eugenio Gastiazoro y Carlos Echagúe. Dichos movimientos se produjeron en un contexto en el que la lucha de tendencias inicial comenzaba a resolverse a favor, por un lado, de la vía insurreccional con foco en la clase obrera industrial y, por otro, de la adopción del

\footnotetext{
${ }^{5}$ A partir de la literatura partidaria y el tratamiento colateral que ha tenido el PCR en la producción académica podemos arriesgar una dimensión de la composición del núcleo fundador. El afluente más numeroso de dirigentes y militantes lo proporciona el PC, fundamentalmente de su juventud. Formaron parte de su núcleo fundador, fundamentalmente, Otto Vargas, Jorge Rocha y José Ratzer: destacados activistas del partido y la FJC. Por otro lado, el MENAP, con quienes el PC codirigió la Federación Universitaria Argentina (FUA), proporcionó en un número menor importantes cuadros, entre ellos Horacio Ciafardini. Por último, otro de los afluentes fue el MALENA, que votó su autodisolución en 1969. De esta organización se incorporó al PCR, de forma individual, Eugenio Gastiazoro. Ver: Andrade Mariano, Para una historia del maoísmo argentino. Entrevista con Otto Vargas, Buenos Aires, Imago Mundi, 2007; Isidoro Gilbert, La FEDE. Alistándose para la revolución. La Federación Juvenil Comunista 1921-2005, Buenos Aires, Sudamericana, 2009; Stella Grenat, Una espada sin cabeza. Las FAL y la construcción de un partido revolucionario en los '70, Buenos Aires, ediciones ryr, 2011; Guido Lissandrelo, "La discusión estratégica en la izquierda argentina en los años '70: Aproximación al debate entre guerrillerismo e insurreccionalismo en el Partido Comunista Revolucionario (PCR), 1967-1972" en Andes [online]. 2015, vol.26, n.1, 00-00.; Pilar Sánchez, El gordo Antonio. Vida, pasión y asesinato del dirigente comunista revolucionario Cesar Godoy Álvarez, Buenos Aires, Ágora, 2008; Julieta Pacheco, Nacional y Popular. El MALENA y la construcción del programa de liberación nacional (1955-1969), Buenos Aires, ryr, 2012.

6 Gilbert, ídem.

7 Esta confusión bien podría entenderse como producto de una convivencia al interior de la organización de diversas tendencias políticas. Lissandrelo, ídem; Andrade, Idem.; Jorge Brega, ¿Ha muerto el comunismo? El maoísmo en argentina. Conversaciones con Otto Vargas, Buenos Aires, Agora, 1990.

8 Posteriormente un reconocido investigador del movimiento obrero argentino.
} 
maoísmo 9 como orientación ideológica excluyente. Esta filiación teórica, oficializada en 1974, cuando tuvo lugar su $3^{\circ}$ Congreso, pero con antecedentes desde 1972, implicó la adopción de la teoría del social imperialismo elaborada por Mao Tsetung (1893-1976) quien consideró la existencia de un escenario en el cual los EEUU y la URSS se disputaban el control imperialista de los países del Tercer Mundo. Con estas herramientas, la situación argentina pasó a leerse en clave de disputa inter-imperialista.

En 1974, en términos programáticos, el PCR definió la contradicción fundamental aún pendiente de resolución en aquella etapa histórica. Respecto de aquella que, por otra parte, determinaría el carácter de la revolución argentina, postulaba que:

opone al imperialismo, la oligarquía terrateniente y el gran capital a ellos asociados, por un lado, y por el otro, a la clase obrera, los campesinos pobres y medios, la pequeña burguesía urbana, la mayoría de los estudiantes e intelectuales y sectores patrióticos y democráticos de la burguesía urbana y rural ${ }^{10}$

A su vez, consideró la Argentina como un país con predominio de relaciones de producción capitalistas, pero deformadas por la dominación imperialista y el latifundio de origen precapitalista, donde las contradicciones solo podrían "resolverse mediante la revolución democrático-popular, agraria, antiimperialista y antimonopolista, en marcha al socialismo."11. En relación con este último punto, el PCR, enumeró las siguientes particularidades:

nuestra revolución será una revolución democrática de nuevo tipo, hegemonizada por el proletariado, y que, como tal, será aliada y parte de la revolución socialista mundial. Durante esta etapa, la contradicción proletariado-burguesía es una contradicción secundaria. Pasará a ser la contradicción fundamental a resolverse en la etapa socialista de nuestra revolución. ${ }^{12}$

\footnotetext{
${ }^{9}$ En cuanto a los orígenes y el proceso de adopción del maoísmo en Argentina, son particularmente valiosos los aportes de Brenda Rupar. Ver: Brenda Rupar, “El Partido Comunista Revolucionario: de su ruptura con el Partido Comunista Argentino a su adopción del maoísmo (1967-1974)", en Brice Calsapeu Losfeld y Miguel Ángel Urrego Ardilla (Coord.), La década roja (1966-1976), IIH/UMSNH, Morelia, 2018 [en publicación]; Brenda Rupar, "El rol de la revolución cultural china en el maoísmo argentino. Las interpretaciones en las visiones oficiales de Vanguardia Comunista y el Partido Comunista Revolucionario", en Leste Vermelho. Revista de Estudos Críticos Asiáticos; Año: 2017 vol. 3, 355 - 375; Brenda Rupar, "Via pacifica ou via armada: os debates na esquerda revolucionária na década de 1960, através de duas organizações maoístas argentinas", en História; Año: 2016 vol. 1, 6 - 24

10 PCR, Documentos aprobados por el PCR a partir de su $2^{\circ}$ Congreso, abril de 1972, hasta su $3^{\circ}$ Congreso, marzo de 1974, Tomo 3, Buenos Aires, Publicaciones $35^{\circ}$ aniversario del PCR, 2005, 93.

11 Idem.

12 Ibid., 94 .
} 


\section{La Historia Argentina}

El PCR tiene, en el marco de nuestra cronología, un acercamiento progresivo a la Historia Argentina. Las puertas de entrada han sido, como veremos a continuación, fundamentalmente tres: la historia de las organizaciones de izquierda, el problema de las clases sociales en el mundo rural y el debate en torno al modo de producción dominante en la región. Estas se encontraron relacionadas directamente con los lineamientos políticos y teóricos que la organización fue hilvanando en pos de constituir una identidad partidaria.

\section{Historia de la izquierda argentina}

El PCR surgió, como PC-CNRR, señalando sus diferencias políticas con la dirección del PC, pero sin poder debatirlas al interior de la estructura partidaria, de forma orgánica. Esto implicó que, una vez afuera, el naciente partido comenzara a elaborar una sostenida crítica a la política de la organización. Tal situación obligó a la formulación de una justificación histórica del natalicio y una explicación del agotamiento del PC como partido revolucionario.

De forma creciente, los expulsados fueron reconociendo en sus producciones "las raíces de la desviación oportunista en el partido" a las que calificaron de profundas y fueron retrocediendo en el tiempo en busca de ellas. En primera instancia, se criticó la influencia que el "browderismo"13 habría tenido en el comunismo criollo desde la década del '40, al otorgarle un rol progresivo a la burguesía nacional y potenciando la vía pacifica de construcción del socialismo. Más precisamente, se señaló que, apoyándose en esas ideas, el PC justificó la alianza con la "burguesía democrática" e incluso con EEUU (luego plasmada en la "Unión Democrática") en contra del peronismo por identificarlo como la expresión criolla del fascismo, concepción que el PCR rechazó desde el primer momento.

Para la naciente organización, en la historia del marxismo criollo se podían detectar la "existencia y perduración de profundas concepciones oportunistas que, en los momentos decisivos, han paralizado o neutralizado al Partido como vanguardia efectiva de la clase obrera y el pueblo, a pesar de las mil veces abnegada labor de sus militantes" 14 . Esto habría imprimido una orientación programática que, en el fondo, sentaba una posición respecto del rol de la burguesía en la revolución argentina:

los errores señalados son manifestaciones de una deformación oportunista que, si bien no cree capacitada a la burguesía nacional para dirigir y realizar las transformaciones revolucionarias agrarias $y$

\footnotetext{
${ }_{13}$ El browderismo, es una corriente ideológica que postula la conciliación entre el comunismo, socialismo y el capitalismo. El concepto deriva del nombre del jefe del Partido Comunista de los Estados Unidos y dirigente del Komintern, Earl Browder, quien postuló durante la Segunda Guerra Mundial la aproximación de su partido al gobierno norteamericano bajo el imperativo de la lucha contra el fascismo.

14 PCR, Documentos aprobados por el PCR - $1^{\circ}$ tomo. Desde la ruptura del PC revisionista hasta su $1^{\circ}$ Congreso (1967 1969), Buenos Aires, Publicaciones $35^{\circ}$ aniversario del PCR, 2003, 37
} 
antiimperialistas, cree, por diversas razones, que solo esa burguesía será capaz de iniciar el proceso revolucionario en el país ${ }^{15}$

A medida que se avanzaba en el tiempo, cuando la ruptura y la expulsión se habían convertido en un hecho irreversible, Otto Vargas, como escriba de la naciente tendencia, desarrolló una crítica que apuntó a atacar la línea partidaria con el objetivo de arrastrar a otras capas militantes. A la vez, el tono de esa voz disidente sería cada vez más tajante y las diferencias que expresaba, más detalladamente expuestas. En síntesis, las criticas mencionadas se proponían, por un lado, a consolidar la nueva organización y, por otro, a clarificar la línea programática. Sin embargo, la dirección del PC logró evitar lo que, en palabras del PCR, constituía potencialmente "una discusión que desentierre las raíces de una tendencia oportunista (...), porque se quiere proyectar hacia el futuro una línea basada en esa tendencia" 16 .

La historia de la izquierda, primero del propio PC y luego de otras tendencias y organizaciones, comenzó a cobrar una ascendente importancia en la tarea de delinear un programa político. De esta manera, una de las funciones de estas primeras intervenciones fue la de establecer un eje problemático para abordar la cuestión:

La desviación oportunista con sus consecuencias sectarias ha tenido sus reflejos en múltiples aspectos organizativos y en las propias concepciones acerca del Partido. El concepto del partido como vanguardia política de la clase obrera se fue desnaturalizando en la práctica y se suplantó por el de "partido de la clase obrera y el pueblo", y, últimamente, en el enunciado de algunos dirigentes, por el de "partido de todo el pueblo". El liquidacionismo (en primer lugar en el movimiento obrero) es una de las más elocuentes consecuencias de esa línea y esa práctica oportunista y antileninista; liquidacionismo en los organismos del Partido como vanguardia efectiva del lugar, y liquidacionismo numérico que trae aparejada la frustración política y el alejamiento de decenas de miles de cuadros y militantes partidarios. ${ }^{17}$

En este sentido, el foco de los análisis fue puesto en la naturaleza de la organización revolucionaria y las formas que, a lo largo de la historia, fueron tomando las organizaciones de vanguardia de la clase obrera. Este elemento volvería a aparecer en ocasión del cambio de nombre de la organización, de ahora en más PCR. Se dio a conocer la decisión de cambiar de nombre, por medio de una resolución interna, publicada en los órganos de difusión del partido, en marzo de 1969, y la de declarar definitivamente irrecuperable la organización que los había expulsado. El naciente partido definió allí su tarea prioritaria

diferenciar clara y tajantemente ante la clase obrera la existencia de dos comunismos. Uno que ha impreso a diversos partidos una desviación

\footnotetext{
15 Ibid., 37.

16 Ibid., 41

17 Ibid., 84 .
} 
oportunista y reformista; y otro que lucha desde diversos destacamentos por recuperar para el comunismo la línea leninista, revolucionaria y de clase (...). Entre estos últimos nos encontramos ${ }^{18}$

Y concluyó señalando que

la diferenciación tiene que marcar el rasgo esencial que divide a los dos comunismos: uno que cree en el paso gradual y evolutivo al socialismo y otro que con criterio consecuentemente científico solo cree en el cambio revolucionario de la sociedad.

Por estas razones, a partir de hoy, nuestro partido pasa a llamarse Partido Comunista Revolucionario de la Argentina y su sigla es PCR. ${ }^{19}$

José Ratzer, uno de los cuadros fundadores del partido, tuvo una intervención concreta que nos anticipa su rol propagandístico en la justificación del naciente partido y su lugar como organizador de la ruptura. En 1966 publicó su libro Los marxistas argentinos del 90, reeditado en 1970 por Pasado y Presente20. En dicho volumen realizó una relectura del nacimiento del socialismo científico en Argentina, atacó la figura de Juan B. Justo y reivindicó la de German Ave Lallemant. Ratzer construye su explicación oponiendo dos corrientes en el seno del socialismo de fines de siglo XIX: una conciliadora y capituladora, encabezada por Justo, y otra consecuente y digna de ser continuada, representada por Lallemant. El dirigente comunista, con anticipación a que la discusión interna tome la forma que reseñamos más arriba, delineó el mismo parámetro para "evaluar" el desempeño y la naturaleza social de las organizaciones. La obra estructura su argumentación en torno de la confrontación de dos variantes diametralmente opuestas del marxismo, en palabras del autor: el revolucionario y el oportunista.

Ratzer comienza el trabajo con una caracterización histórica de Argentina en la que se recuperan las tesis de Leonardo Paso (1910-2008) y Héctor P. Agosti (1911-1984), historiadores oficiales del PC. De esta forma, el carácter feudal y atrasado que la colonia imprimió al territorio rioplatense se constituye como el punto de partida. En este sentido, 1880 es elegida como la década en la que se establece el "esquema de clases que habría de prolongarse hasta nuestros días", esto es, una Argentina con predominio latifundista asentado en una oligarquía terrateniente íntimamente asociada con capitalismo inglés, con una burguesía contradictoria, dual y oscilante, y un proletariado en expansión, predestinado a hacer la revolución ${ }^{21}$.

Para comprenderla en todas sus dimensiones, esta obra exige ser leída focalizando en el contexto de su producción y publicación. Desde tal perspectiva puede observarse que el trabajo que se habría terminado de escribir en 1966, momentos en que ya se encontraba latente la división al interior del PC. Al mismo tiempo se advierte que aunque el trabajo no

\footnotetext{
18 Ibid., 243

19 Ibid., 244.

20 José Ratzer, Los marxistas argentinos del 90, Buenos Aires, Pasado y Presente, 1970.

21 Ratzer, op. cit., 9-24.
} 
hiciera una referencia directa a su presente, su autor reclamó que se lo enmarcara en la lucha ideológica de su contexto. El libro tiene una función legitimadora frente a su viejo partido; las desviaciones oportunistas vendrían a ser suplidas por la nueva organización que, estudiando el pasado del comunismo local, estaría en condiciones de neutralizar dichas tendencias en el presente y construir el partido revolucionario del proletariado argentino. Este tipo de trabajos, de lectura crítica de la izquierda argentina, son muy propios del período, en el que se registraban rupturas cada vez mayores en el socialismo y el comunismo a partir, fundamentalmente, del fenómeno peronista, el XX Congreso del Partido Comunista de la Unión Soviética y la revolución cubana. Las revalorizaciones, en este contexto, apuntaron a construir un linaje, mediante el rescate selectivo de determinadas figuras marginadas, del cual se reclamaron continuadores ${ }^{22}$.

En la misma dirección, ya con la editorial partidaria Ágora funcionando ${ }^{23}$ y el autor fallecido, se publicó en 1981 El movimiento socialista en Argentina ${ }^{24}$, que aborda los orígenes del PC. En sus páginas, donde es notable su carácter de obra inconclusa, es incorporada como marco teórico fundamental la literatura partidaria que había visto la luz los años previos y había sentado posición sobre los temas candentes de la historia nacional ${ }^{25}$. Y, si bien las ideas aquí desarrolladas representan una profundización de la obra anterior, este segundo libro comenzaba a abordar los orígenes del PC cuya composición e ideas iniciales se analizan. Esta área temática representaba un gran punto de interés para el partido que, publicando este último libro inconcluso de Ratzer, tendió un puente que le permitió reforzar la familiaridad argumentativa y crear un linaje ascendente.

La idea central de estos escritos que será retomado por Vargas, en su libro El marxismo y la revolución argentina ${ }^{26}$, está asociada a la herencia vacante que habría dejado el marxismo-leninismo en su existencia criolla. Según lo postulado por Ratzer, a través de la historia nacional se habrían expresado los elementos que asegurarían una continuidad teórica a pesar de las desviaciones revisionistas. En este sentido, Vargas, profundizando la hipótesis de trabajo de Ratzer, sostiene

A pesar de todas las derrotas, la corriente marxista no había muerto en el seno del Partido Socialista, y lo que pasaba en el país y el mundo favorecía una nueva expresión de la misma. ${ }^{27}$

\footnotetext{
22 Horacio Tarcus, El marxismo olvidado en la Argentina: Silvio Frondizi y Milciades Peña, Buenos Aires, Ediciones El Cielo por Asalto, 1996.

${ }^{23}$ El registro más antiguo de su funcionamiento lo encontramos en torno al año 1980. Previamente el partido editó con el sello "ediciones de Mayo".

24 José Ratzer, El movimiento socialista en Argentina, Buenos Aires, Ediciones Agora, 1981.

25 “La comprensión de la historia argentina, carente de un análisis marxista durante décadas, ha cobrado nuevo impulso con la aparición del libro de Rosendo Irusta, impulso que proseguirá sin duda con el trabajo de Eugenio Gastiazoro: Introducción al análisis económico-social de la historia argentina, ed. Agora, Buenos Aires, 1980", en: Ratzer, op. cit., 26.

26 Otto Vargas, El marxismo y la revolución argentina, Buenos Aires, Agora, 1987.

27 Ibid., 124.
} 
De esta manera se construye una historia que toma como eje los balances críticos sobre las líneas de intervención concreta en la realidad nacional. Según Vargas, en los hechos, las posiciones que fue tomando el PCR implicaron una crítica del pasado y una ruptura con este: entendiendo que ese movimiento había conllevado un quiebre con el desarrollo "natural" del pasado, la ruptura con el PC habría una necesidad histórica creada por múltiples factores. En este sentido, la responsabilidad histórica del partido revolucionario se encontraría en disputa y su análisis debía cobrar un carácter activo frente a las tergiversaciones que, para el propio partido, se realizaban de la historia del marxismo y la clase obrera:

Por eso es tan importante conocer bien ese pasado, que siempre palpita en el presente, para saber qué es lo que ha sido o debe ser negado de él y, tal vez, sobrevive en nosotros. Esto implica no sólo una revisión teórica de ese pasado sino también, y principalmente, una crítica política del mismo. Quienes nos precedieron en la lucha por el comunismo cometieron muchos errores. En ocasiones dieron opiniones y formularon juicios erróneos. Pero sólo conociendo bien en lo que acertaron y en lo que se equivocaron podremos cumplir con nuestra responsabilidad histórica. ${ }^{28}$

De esta manera, se expuso un plan de indagación cuya génesis se ubica en aportes previos:

El tema sobre el cual escribo estas líneas tuvo, en el movimiento obrero y comunista argentino un gran especialista: José Ratzer. El murió, cuando preparaba su historia del Partido Comunista de la Argentina, obra a la que dedicó años de investigación. Con ella se hubiese escrito, como él quería, una "historia del partido político obrero" en nuestro país. Me limitaré a analizar en forma sintética el proceso de fusión del marxismo con el movimiento obrero argentino y su integración con nuestro movimiento revolucionario. Así como en muy pocas ocasiones los ríos son tales desde su inicio, y la mayoría nace en hilos de agua que poco a poco van confluyendo en el cauce por donde aquel correrá, así también fue el proceso que llevó a aquella fusión y a esa integración. ${ }^{29}$

Vargas enmarca su trabajo en una genealogía cuya figura central es Ratzer y, al mismo tiempo, aporta un nuevo elemento: el problema de la fusión entre el marxismo y el proletariado argentino, cuestión que preocupaba sobremanera al partido, a raíz del desarrollo de su política en frentes de masas en los que se reconocía al nacionalismo como la ideología dominante. Partiendo de un análisis no cronológico y poniendo énfasis en las luchas de tendencias, Vargas se propone una historia donde el conflicto ocupa un lugar central.

${ }^{28} \mathrm{Ibid} ., 4$.

29 Idem. 
De acuerdo con el cambio del grupo dirigente de los '70 que enunciamos más arriba, será Otto Vargas, secretario general del partido desde su fundación, quien continúe con esta línea de investigación esbozada por Ratzer. La forma que tomó el tratamiento de la historia de la izquierda local y mundial realizó un recorrido ascendente: si en sus primeras aproximaciones las referencias documentales y la profundidad fueron más bien escasas, con el tiempo, los análisis, impulsados por las propuestas analíticas de Ratzer, cobraron mayor profundidad y solidez documental. Esta perspectiva será profundizada por Vargas que publicó en 1999 el segundo tomo de la obra, que abarca desde la fundación del PC hasta la década del ' $30^{30}$.

\section{La cuestión agraria}

El PC-CNRR advirtió, en su documento destinado al XIII Congreso del PC (1968), la existencia en el país de una oligarquía terrateniente que, en alianza con el capital monopólico imperialista, se encontraba beneficiada por un proceso modernizador de tipo "prusiano". Este camino consistía en una creciente modernización de los latifundios, que les inyectaba capital y tecnología, gracias a la cual se conservaba el régimen de propiedad de la tierra. A su vez, se definió su impacto social y político: “un aumento constante del peso y la importancia del proletariado rural, el aumento de las contradicciones sociales del campo y la agudización de la lucha de clases en el mismo"31. Frente a este pronóstico el partido estableció la necesidad de estructurar una organización nacional que agrupara y representara a los campesinos pobres y medios golpeados por ese desarrollo modernizador que implicaba una creciente concentración de la propiedad de la tierra 32.

Como idea inicial, tratando de delimitarse del PC, el naciente partido, ya constituido como PCR en las vísperas de su Primer Congreso (1969), instó a sus militantes a "liquidar de cuajo las ideas que subestiman la importancia del trabajo agrario (...)"33. Según el flamante partido, debía ser superado el hecho de no tener en cuenta al proletariado rural, "pecado tradicional de la izquierda argentina, causal en gran medida del fracaso histórico del Partido Socialista y el codovillismo" 34 . De esta manera, se declaraba la necesidad de establecer un trabajo sistemático en el campo y se establecieron parámetros para iniciarlo. En primer lugar, se advirtió la necesidad del sostenimiento de un trabajo permanente y minucioso, considerando que cada lugar físico precisaba un "conocimiento profundo de la zona: su estructura social, economía, costumbres"35. Y, en segundo término, llamó a su Congreso a "fijar un plan político y organizativo que permita comenzar a trabajar en el proletariado rural y el campesinado pobre y medio" 36 . Estas

\footnotetext{
30 Otto Vargas, El marxismo y la revolución argentina, Tomo II, Buenos Aires, Ágora, 1999.

31 PCR, op. cit., 183.

32 Idem.

33 Ibid., 372.

34 Idem.

35 Ibid., 373.

36 Idem.
} 
ideas iniciales supusieron colocar la cuestión agraria como un tema de discusión primordial en las filas de la organización que se encontraba en plena formación.

En sintonía con esto, la revista teórica del partido otorgó gran importancia a la temática, debido a su relevancia como componente del programa partidario. En sus páginas encontramos una serie de artículos que, como veremos, establecieron un diálogo en torno a esta problemática. En el número dos de Teoría y Política (TyP), de 1969, se publicó un trabajo titulado Argentina 1880-1914. Notas sobre capitalismo, prusianismo y dependencia que inaugura la problemática ${ }^{37}$. En él, Andrés Marín, seudónimo de Julio Godio, analizaba un periodo considerado punto de inflexión en la historia del país, por condensarse en él las transformaciones que habrían desembocaran en un capitalismo dependiente. Recurriendo a las ideas centrales de Lenin en su obra El imperialismo fase superior del capitalismo (1916) y citando su obra La economía argentina (1968) de Aldo Ferrer, el autor estructuró una explicación en la cual se caracterizaba al capitalismo argentino como dependiente y con resabios precapitalistas. El eje central era demostrar que en la Argentina no se había operado un desarrollo capitalista autónomo y que el imperialismo, inglés en primera instancia, se sirvió de estructuras precapitalistas (como el latifundio) para establecer su dominio económico, primero en el mercado externo y luego en el interno, para desarrollar un capitalismo sobre la base de la producción agrícolo-ganadera. La conclusión a la que arribaba el autor, respecto a la naturaleza de este régimen, era que las relaciones de producción capitalistas se habían abierto paso no contra la gran propiedad territorial, sino sobre ella. Todo esto habría sido posible, según el dirigente comunista, por la ausencia de una burguesía nacional capaz de desarrollar sus intereses históricos, por un lado, y por una excepcionalidad argentina, la gran extensión de tierras en el Litoral y la existencia de un sistema de explotaciones ganaderas apto para satisfacer las necesidades alimenticias europeas, por otro.

En su intento por encontrar los antecedentes históricos al periodo de su análisis, Godio, sostiene la tesis de colonización feudal de América Latina, a partir de la cual, para el área rioplatense, caracteriza al feudalismo como tardío. Este régimen se habría dado, en el Río de la Plata, como producto de la ausencia de metales preciosos, recién en el siglo XVIII cuando se valorizó el ganado cimarrón. Esto explicaría, según el autor, que las relaciones semifeudales que se establecieron hayan sido menos ostensibles que en las zonas de colonización temprana, como el mundo andino. Las conclusiones políticas que se desprenden del análisis establecen al proletariado urbano y rural como los únicos sujetos históricos capaces de superar los límites impuestos por el imperialismo en el desarrollo nacional.

Roque Galván ${ }^{38}$ retomó en el $4^{\circ}$ número de la revista -casi dos años más tarde- la cuestión agraria ${ }^{39}$. Incorporando la caracterización esbozada por Marin y apoyándose en el

\footnotetext{
37 Andrés Marín, “Argentina 1880-1914. Notas sobre capitalismo, prusianismo y dependencia”, en Teoría y Política, n², año I, Buenos Aires, 1969, 93-115.

38 Bajo este seudónimo escribía Eugenio Gastiazoro. Entrevista a Eugenio Gastiazoro realizada por el autor en abril de 2018.

39 Roque Galván, “Acerca del problema agrario en nuestro país”, en Teoría y Política n4, Buenos Aires, año III, 1971, 31-50.
} 
censo agrario de 1960 profundizó en la problemática de la propiedad de la tierra desde la perspectiva de la productividad y las clases sociales que se enfrentan en dicho proceso. El autor, recurriendo a los datos censales e incorporando ejemplos de situaciones históricas previas, concluyó que la principal traba a la expansión de las fuerzas productivas en el campo se originaba en la propiedad privada latifundista que habría implicado la apropiación, por parte del terrateniente, de la renta absoluta.

Este artículo, a diferencia del anterior, introdujo el análisis del peronismo. Allí, este movimiento, fue criticado por sus límites para estructurar una nación capitalista autónoma: pactar con los terratenientes y el imperialismo el sostenimiento de la gran propiedad de la tierra para no trastrocar las bases que sustentaban la estructura económica. Al señalar la propiedad de la tierra como el principal problema, el autor derivó que la revolución que plantea el desarrollo histórico nacional tenia características democráticas, por su contenido (nacionalización de la tierra), y estaría dirigida a eliminar la base del poder oligárquico: la propiedad privada latifundista.

En el $5^{\circ}$ número de TyP en 1971, Pedro Serdán ${ }^{40}$ publicó un estudio de caso titulado Acerca de la clase obrera rural (en una parte de la Pampa húmeda) ${ }^{41}$. A partir del señalamiento de que su estudio estaba relacionado con las directivas del partido, realizó un recorrido histórico sobre esta clase social con el objetivo de establecer la estrategia correcta para un trabajo político sistemático sobre ella. Su intención era discutir lo resuelto por el partido en ocasión del $1^{\circ}$ Congreso (1969):

En la zona de la Pampa Húmeda debemos comenzar a trabajar entre el proletariado rural. Es posible y necesario hacerlo ya en los zonales de Bahía Blanca, Pehuajó, Mar del Plata, Pergamino y zona cuatro, Rosario, Santa Fe, Córdoba y organizar el trabajo de los estudiantes del interior durante las vacaciones, y las vinculaciones existentes con una cantidad importante de afiliados y amigos del Partido en pueblos y localidades de esas provincias. ${ }^{42}$

El artículo presentó algunas divergencias con el informe del comité central del PCR sobre la situación en la pampa húmeda, sobre todo con respecto al impacto que había tenido allí el peronismo. Para el autor, este no había defendido al proletariado rural, sino que había actuado como su barrera de contención, y, al promover políticas de mecanización del trabajo, había contribuido a la expulsión de población del campo a la ciudad, tendencia que se profundizaría luego de 1955, según Serdán.

Este análisis de caso, que se asienta sobre los censos que van desde principios del siglo XX hasta el de 1969, construye una explicación histórica de la estructura social en el campo, se centra en la zona sur de Santa Fe y marca una tendencia general hacia la creciente especialización del trabajo rural. Frente a esto, Serdán propone orientar el trabajo

\footnotetext{
40 Desconocemos, por el momento, la identidad real de dicha persona, su lugar de militancia y su procedencia.

${ }^{41}$ Pedro Serdán, "Acerca de la clase obrera rural (en una parte de la pampa húmeda)", en: Teoría y Política, n5, año III, 1971, 27-35.

42 PCR, op. cit., 372
} 
del partido independientemente del proletariado rural, que tendía a desaparecer, y focalizar el trabajo partidario sobre las zonas de concentración industrial, y los intelectuales y profesionales de las ciudades.

Jose Ratzer y Julio Godio, en el siguiente número de la revista, salieron al cruce de las conclusiones políticas que se desprenden del análisis de Serdan ${ }^{43}$. Sin impugnar el estudio de caso desarrollado, los dirigentes del PCR sentenciaron que sus conclusiones implicaban la simplificación de una situación compleja y que el partido debía actuar sobre las clases explotadas del campo, fundamentalmente el proletariado rural y los campesinos pobres, aunque la tendencia, demostrada en aquellos datos censales, evidenciaba su desaparición como tal.

En esta serie de artículos, las intervenciones tienen una lógica acumulativa en cuanto a la información expuesta y los datos reseñados. La impugnación hecha por José Ratzer y Godio a las conclusiones políticas presentadas por Serdan demuestra que las investigaciones desarrolladas por los cuadros del partido estaban inspiradas por las resoluciones congresales y los documentos programáticos, y que, en última instancia, el núcleo de discusión eran las consecuencias prácticas que emanaban de estos y no el método de análisis. El análisis histórico o lo que, en apariencia, es una clara investigación empírica se encuentra totalmente subordinado a la política que el partido intentó desenvolver de cara a los explotados del campo, para combatir a su principal enemigo: los terratenientes.

En ellos las citas de autoridad a libros clásicos del marxismo abundan, pero también son citados autores que se han especializado en la academia como Cortez Conde, Gino Germani, Tulio Halperin Donghi, Aldo Ferrer, Sergio Bagú y Rodney Arismendi. Inclusive se cita a autores de corte militante como Milciades Peña (1933-1965) o Leonardo Paso. Estas citas tienen la particularidad de instrumentalizar argumentos o informaciones en pos de sostener la tesis propuesta más que el debate abierto y frontal con aquellos.

El tema, aunque continuó estando presente en las formulaciones programáticas y el debate partidario, pasó a un segundo plano. A simple vista, podemos atribuir este desplazamiento al creciente protagonismo que el partido fue adquiriendo en los gremios industriales y los importantes debates que se libraron en torno a ellos: fundamentalmente la "hegemonía proletaria" en la revolución y las formas de lucha del proletariado argentino, con su expresión insurreccional. Este movimiento se ve en ocasión del Segundo Congreso (1972) cuando el partido caracterizó que, producto de la creciente combatividad del proletariado industrial, despertaron al combate todas las clases sociales ${ }^{44}$. En ese contexto, se señaló que, a pesar de la existencia de grandes concentraciones de productores agrarios en diversas regiones del país, las luchas libradas por el proletariado rural se habían visto "hegemonizadas por el campesinado rico e, incluso, por los terratenientes" 45.

\footnotetext{
43 Andrés Marín, y Lucas Figarí, “El método para analizar la lucha de clases en el campo", en Teoría y Política n6, año III, 1971, 49-56.

44 PCR, Documentos aprobados por el PCR a partir de su $1^{\circ}$ Congreso, diciembre de 1969 , hasta su $2^{\circ}$ Congreso, abril de 1972, Publicaciones $35^{\circ}$ aniversario, Buenos Aires, 2005, 204

45 Idem.
} 
En ese contexto, el partido volvió a remarcar el rol estratégico que cumpliría el proletariado rural, cuya incorporación a la lucha revolucionaria, arrastrando al campesinado pobre, consideraba necesaria para el triunfo del proletariado.

El balance de lo actuado se encontraba lejos del optimismo. En aquella ocasión se remarcaron la falta de un conocimiento útil sobre el tema, la carencia de una actividad integral del partido y la necesidad de superar los intentos aislados de penetración en el mundo rural. Frente al avance que el partido iba conquistando con las Agrupaciones Clasistas $1^{\circ}$ de Mayo en los centros industriales del país, se propuso desarrollar el mismo guion de acción:

agrupación de los obreros más avanzados con el objeto de recuperar sindicatos existentes, y estructurarlos allí donde no existan, en base al desarrollo de los principios de la democracia proletaria y aprehendiendo el torrente clasista revolucionario en la clase obrera rural. Aquí, con las particularidades del caso, es aplicable nuestra política general con el movimiento obrero ${ }^{46}$

A medida que la temática iba perdiendo protagonismo en los documentos programáticos y en las publicaciones teóricas, el partido fue abandonando una elaboración sistemática y específica, lo que puso en evidencia que, a pesar de sus intenciones e intentos, no había logrado conquistar posiciones significativas en el ámbito rural. En este sentido, se fue subordinando la elaboración de una estrategia partidaria para el proletariado rural en pos de copiar el ejemplo de una experiencia satisfactoria como la de los agrupamientos sindicales y el sindicato mecánico cordobés.

Fue en 1984, en el contexto del cuarto congreso partidario, cuando tema volvió a cobrar importancia como consecuencia de una lectura del contexto. En enero de 1984 el partido, sostuvo que:

En esta situación, y a semejanza del periodo 1969-1976, la oleada de luchas arrancó del interior. Pero a diferencia de aquellas, estas fueron iniciadas por sectores agrarios y plegaron solidariamente a las ciudades. (...) Fueron los campesinos pobres y medios de la Pampa Húmeda, en lucha por no pagar el impuesto inmobiliario los que iniciaron el movimiento (...) pero en general el movimiento fue hegemonizado por terratenientes, grandes capitalistas y campesinos ricos (...). Estos hechos pusieron de relieve que, así como sólo una persistente política de concentración en las grandes empresas permite crecer en el movimiento obrero, sólo una política de concentración permite crecer en el campo; pues allí además de poner la cabeza, es necesario poner los pies. ${ }^{47}$

\footnotetext{
46 Ibid., 212.

47 PCR, Documentos aprobados por el PCR a partir de su $3^{\circ}$ Congreso, marzo de 1974, hasta su $4^{\circ}$ Congreso, abril de 1984 (segunda parte 1980-1984), Tomo 4, Publicaciones 35ªniversario del PCR, Buenos Aires, 381-382.
} 
De esta manera, se señaló la importancia que, para el partido, iba adquiriendo el mundo rural en la escena política nacional frente a una clase obrera golpeada por la desocupación. Esto, además de diseñar una estrategia política, implicó señalar, nuevamente, las dificultades de dicho ámbito y la necesidad de conocerlo en profundidad:

En este proceso se evidenció la necesidad de profundizar nuestro conocimiento concreto, en cada zona, de las clases en el campo. Clases que, como señala el marxismo, se diferencian por el lugar concreto que ocupan en la producción. Y la necesidad de dar una lucha más consecuente por basarnos en los pobres, aliarnos con los campesinos medios y neutralizar a los ricos, en nuestra lucha anti terrateniente y antimonopolista $^{48}$

En consonancia, se denunció la necesidad de cambiar la estrategia -frente a experiencias puntuales en las que el partido advertía haber quedado "pegado" a sectores ricos- intentando ligar, en el trabajo político, a los obreros rurales con los campesinos ${ }^{49}$.

En ocasión del congreso hubo debates en torno a la existencia o no de los sectores proletarios y campesinos pobres, cuestión que quedó pendiente de demostrar con datos empíricos ${ }^{50}$. Ante este problema, Vargas pronunció una serie de conferencias en julio de 1986 destinadas a establecer una posición oficial. A partir de una investigación realizada en dos localidades de la Pampa Húmeda (Colón y Wheelwright), en ese contexto zona sojera, se llegó a la conclusión de que la mayoría de la población campesina era "semiproletaria o productores pobres y medios" y de que, a pesar del desarrollo capitalista operado en la zona, los terratenientes "aburguesados" continuaban con prácticas semifeudales para la explotación de mano de obra.

Este trabajo operó como la última palabra, de parte de la dirección del partido, en el debate y se colocó en sintonía con los trabajos de Eugenio Gastiazoro ${ }^{51}$ al concluir que:

Sin acabar con el latifundio y su carga de renta agraria no habrá progreso posible para la argentina, y el país seguirá hundiéndose en la crisis crónica propia de los países del Tercer Mundo que no han realizado la revolución agraria y antiimperialista ${ }^{52}$

\footnotetext{
48 Ibid., 382.

49 Idem.

50 Otto Vargas, en una serie de conferencias dictadas en julio de 1986, da cuenta de ello al señalar que "hubo un debate intenso cuando compañeros que estaban en el trabajo agrario plantearon que en la pampa húmeda no habia campesinos pobres". Otto Vargas, Los Ignorados, Buenos Aires, Cuadernos de Agora II, $1992,27$.

51 Eugenio Gastiazoro, Historia argentina. Introducción al análisis económico/social. Tomo I (1515-1820), Buenos Aires: Ágora; Eugenio Gastiazoro, Historia Argentina. Introducción al análisis económico/social, Tomo II (18201880), Ágora, Buenos Aires, 1980; Eugenio Gastiazoro, Historia Argentina. Introducción al análisis económico/social, Tomo III (1880-1930), Ágora, Buenos Aires, 1986.

52 Vargas, op. cit., 62.
} 
De esta manera, la posición política cimentada en un análisis "histórico" entró en el corpus programático e historiográfico que fue construyendo el partido.

\section{El modo de producción dominante}

El problema del modo de producción dominante en América Latina es, quizás, uno de los más discutidos por la izquierda argentina a lo largo de los años sesenta y setenta. Tomar posición frente al pasado colonial y, en consecuencia, diagnosticar el carácter de la revolución futura ocupó, en ese periodo, el centro de la escena en lo respectivo a la elaboración teórica del marxismo militante. Incluso, si observamos la producción historiográfica de las corrientes de izquierda a lo largo del siglo $\mathrm{XX}$, se puede advertir que cada una de ellas ha sentado posición, al menos tentativa, sobre dicha problemática ${ }^{53}$. Particularmente en este caso y en ese momento (1960-1970), al tratarse de una organización que surge de la ruptura de uno de los partidos más longevos y con mayor producción intelectual del país, la herencia es sólida y voluminosa. En este sentido, remarcamos que la tesis de colonización feudal de América Latina, formulada por el PC, formó parte del bagaje teórico de los militantes expulsados que fundaron el PCR. Sin embargo, como veremos, el naciente partido sentó su propia posición al respecto y estructuró sus propios soportes.

Horacio Ciafardini, militante primero del MENAP y luego del PCR, tuvo una intervención pública en torno a este debate en el célebre cuaderno $\mathrm{N}^{\circ} 40$ de Pasado y Presente (PyP) sobre los Modos de producción en América Latina ${ }^{54}$. En él, Ciafardini, economista con inserción académica, centrando su atención en el concepto de "Capitalismo Comercial" y mediante un análisis conceptual de El Capital de Marx, criticó los planteos circulacionistas de André Gunder Frank (1929-2005). En este sentido, el autor puso énfasis en demostrar que la expresión "capitalismo comercial" era inadecuada para el estudio de la realidad latinoamericana y que, en todo caso -siguiendo a Marx-, esta categoría solamente sería adecuada para analizar la prehistoria del capitalismo y no expresaría la realización del mismo. Sin embargo, esta intervención no planteó una resolución que implique la clasificación del modo de producción hegemónico en el continente y la descripción del mismo, en todo caso se constituye como un aporte de corte metodológico que, de todas maneras, se acerca a la tesis feudal.

Este célebre libro, muy comentado y leído en los círculos intelectuales de izquierda del período, impulsó al PCR, particularmente a sus sectores intelectuales, a pensar el problema y reconocer la necesidad de sentar una posición orgánica sobre el mismo. De esta manera, se explica que un tema que no había merecido comentario alguno en los documentos partidarios haga su aparición en el Programa aprobado por el $3^{\circ}$ Congreso partidario de 1974. Allí se sostuvo, en el marco de la caracterización del país, que

\footnotetext{
53 Ver: Acha, Idem.; Campione, Idem.; Pagano y Devoto, Idem.

54 Horacio Ciafardini, "Capital, comercio y capitalismo: a propósito del llamado 'capitalismo comercial", en: VV. AA., Modos de producción en América Latina, Córdoba, Cuadernos de Pasado y Presente, 1973, 111-134.
} 
Pese a que las colonias españolas en América, y en nuestro caso particular del Virreinato del Rio de la Plata, estuvieron vinculadas desde su origen al capitalismo naciente, y lo fundamental de su producción fue una producción mercantil, las relaciones de producción imperantes, y la superestructura jurídica y política, fueron feudales. Ni la 'hibridez' de las relaciones de producción imperantes en la colonia (...), ni las diferencias existentes entre distintas regiones (...), que fueron importantísimas en la determinación de los procesos históricos previos y posteriores a la independencia, anulan la esencia feudal del Virreinato. ${ }^{55}$

¿Por qué a partir de ese momento una problemática que había permanecido ausente en las formulaciones partidarias mereció una resolución congresal? Por un lado, el partido había tenido desde su fundación una relación de discusión y colaboración con el grupo PyP. Esto puso en contacto, a los intelectuales partidarios y sus dirigentes, con bibliografía y autores que posiblemente hayan empujado a la organización a intentar ser parte de un debate general en el mundo de la izquierda ${ }^{56}$. Por otro lado, para el partido implicó, como veremos, la apertura de una oportunidad para sentar posición, directamente relacionada con sus planteamientos en cuanto a la naturaleza de la sociedad y economía argentina, y realizar un ajuste de cuentas con todo el espectro político de la izquierda criolla.

Luego del congreso partidario, la revista Los Libros ${ }^{57}$ publicó, por un lado, un trabajo sobre el feudalismo y el capitalismo en la historia latinoamericana ${ }^{58}$ de Manfred Kossok ${ }^{59}$ y, por otro, una reseña de dos obras que analizaban la definición de feudalismo ${ }^{60}$

55 PCR, Documentos aprobados por el PCR a partir de su $2^{\circ}$ Congreso, abril de 1972, hasta su $3^{\circ}$ Congreso, marzo de 1974. Tomo 3, Publicaciones $35^{\circ}$ aniversario del PCR, 2005, 94.

56 Horacio Crespo explica, en base a testimonios personales y recolectados, la relación que tuvieron el grupo PyP y el PCR. Primero de simpatía y colaboración (1967-19173/4) y luego, a partir de sus divergentes posiciones políticas y teóricas, de distanciamiento. Si bien José Arico, quien dirigió este grupo, no se integró al naciente partido si lo hicieron algunos de sus colaboradores y miembros de la revista. Por otro lado, miembros del partido como Jose Ratzer, Horacio Ciafardini, Carlos Echague y Carlos Altamirano se integraron al trabajo de los Cuadernos editados por el grupo PyP, colaborando en elaboraciones, traducciones, etc. Horacio Crespo, “En torno a los Cuadernos de Pasado y Presente, 1968-1983", en El político y el científico: Ensayos en homenaje a Juan Carlos Portantiero, editado por Claudia Hilb, Buenos Aires: Siglo XXI/UBA Facultad de Ciencias Sociales, 2009, s/p.

57 Esta revista, fundada en 1969 y cerrada en 1976 luego del golpe militar, es dirigida en un primer momento por Héctor Schmucler, uno de los fundadores de PyP. A finales de 1971 se integran al Consejo de Dirección Carlos Altamirano (militante del PCR) y Ricardo Piglia (cercano a Vanguardia Comunista, organización maoísta argentina). Inmediatamente, en marzo de 1972, se sumó Beatriz Sarlo (también militante del PCR) a la dirección y en 1973 Schmucler abandona la publicación. Adrian Celentano, "Insurrección y compromiso intelectual. Los Libros y Cristianismo y Revolución frente al Cordobazo y el Viborazo", en Archivos, año II, N 4 , marzo de 2014, 53-74.

58 Manfred Kossok, "Feudalismo y capitalismo en la historia de América Latina”, en Los Libros, N 37, Buenos Aires, septiembre-octubre 1974, 13-19.

59 Historiador académico de la Alemania soviética, especialista en historia colonial y revoluciones de independencia latinoamericanas.

60 “VV. AA., El feudalismo, Segunda edición, Madrid, Ayuso, 1973. 
escrita por H. Ciafardini. Es notable como, en este momento, la preocupación del economista argentino radicó en puntualizar la cuestión conceptual y terminológica, en la misma línea que como lo había hecho en la publicación de PyP y, como veremos a continuación, lo haría en el futuro en los soportes partidarios.

Ciafardini publicó artículos en la revista TyP en varias oportunidades. Para el análisis de esta temática nos interesan, fundamentalmente, dos intervenciones escritas bajo el seudónimo de Hugo Páez. Particularmente sus intervenciones se dirigieron a atacar la "teoría de la dependencia". Lo hizo desde una perspectiva metodológica y programática. En las páginas de la revista se acusó a los representantes de esta teoría de ser portadores de una visión unilateral y simplista de la historia, siendo la cuestión de las burguesías nacionales y la opresión imperialista el punto neurálgico de la divergencia61. Ciafardini, en pos de sentar una posición, señaló la importancia de incorporar al análisis la historia española y así puso énfasis en la diferencia entre prehistoria del capital y desarrollo del capitalismo. De esta manera, el autor retomó aspectos expuestos en su intervención en el cuaderno N40 de PyP y remarcó lo erróneo de ver, en la circulación, el desarrollo del capital: debido a que este se podía dar, en su perspectiva, independientemente del desarrollo de relaciones de producción capitalistas. A su vez, remarcó que este desarrollo podía implicar, como en el caso español, una hegemonía de sectores dominantes de la sociedad feudal, situación que en este caso determinaría la conformación de España como un país subordinado al mercado mundial. De esta manera el autor señaló que, en América Latina, más allá del impulso al capitalismo que implicó la extracción de metales preciosos, subsistieron rasgos feudales que impidieron un desarrollo pleno del mismo. Ciafardini concluye su análisis postulando que el principal "error" sería plantear una revolución socialista donde, para él y el PCR, lo que estaba a la orden del día es una revolución democrática y nacional. ${ }^{62}$

Estos planteos iniciales fueron determinantes y marcaron el derrotero que sistematizó la respuesta más ordenada e integral a la cuestión del modo de producción en América Latina que, por parte del PCR, desarrolló Otto Vargas, bajo el pseudónimo de Rosendo Irusta, posteriormente. Entre 1976 y 1977 aparecieron dos extensos artículos destinados a sentar posición sobre este tema en la revista teórica del partido63. A su vez, estos documentos se editaron en formato de folleto a fines de 197764 y en 1983 vio la luz el

\footnotetext{
Witold Kula, Teoría económica del sistema feudal, Buenos Aires, Siglo XXI, 1974". Ver: Horacio Ciafardini, "Feudalismo: economía y sociedad", en Los Libros, N³7, Buenos Aires, septiembre-octubre 1974, 20-22.

61 Hugo Páez, "Teoría de la dependencia: inútil contra el viejo amo, útil para el nuevo”, en Teoría y Política n'14, año VI, 1975, 14-23.

62 Hugo Páez, "Sobre algunos enfoques unilaterales de la historia”, en Teoría y Política, n¹7, año VII, 1976, 2023.

63 Rosendo Irusta, "Sobre el modo de producción dominante en el Virreinato del Rio de la Plata", en Teoría y Política, n¹7, año VII, 1976, pp. 9-19; Rosendo Irusta, "Sobre el modo de producción dominante en el Virreinato del Rio de la Plata ( $2^{\circ}$ Parte)", en Teoría y Política, n¹8, año VIII, 1977, 4-50.

64 Rosendo Irusta, Sobre el modo de producción dominante en el virreinato del Rio de la Plata, Buenos Aires, Ediciones de Mayo, 1977.
} 
formato libro65. Estos tuvieron un tono polémico y buscaron sistematizar una posición que emanaba del programa del partido, aprobado en el $3^{\circ}$ Congreso (1974), que citamos más arriba.

El trabajo de Vargas está estructurado en dos partes. La primera se ocupa de ajustar cuentas con las tendencias historiográficas y políticas que intervinieron en el debate y la segunda analiza una serie de elementos y procesos históricos que desembocan en un diagnostico final. Los oponentes son aquellos que sostuvieron la tesis capitalista de colonización (Gunder Frank, Sergio Bagú, Milciades Peña, P. M. Sweezy) y quienes postularon la diversidad y convivencia de distintos modos de producción en el Río de la Plata, tratándose de un caso particular donde ni lo feudal ni lo capitalista seria hegemónico (Carlos Assadourian, Ernesto Laclau, Juan Carlos Garavaglia, Santana Cardoso, Leonardo Paso y Enrique Tandeter). Vargas destacó la inexistencia de un modelo puro de capitalismo o feudalismo, pero remarcó que esto no negaría la existencia de leyes universales que regirían el desarrollo de las sociedades.

Estas "desviaciones" son combatidas por Vargas en cuanto a las implicancias políticas que arrastrarían. El eje central de esta crítica esta sostenido en la necesidad de conocer, mediante el materialismo histórico, el pasado para comprender las tareas del presente, en clave de lucha de clases. En este sentido se retomó la lógica argumentativa presente en el trabajo de José Ratzer que mencionamos más arriba, donde solo existían marxistas y revisionistas en el campo político e historiográfico.

En la segunda parte del trabajo, Vargas se ocupó de realizar una explicación del desarrollo histórico desde el poblamiento del continente americano hasta la rebelión de Tupac Amaru (1780). La explicación la construye sobre factores políticos, institucionales y sociales, con un fuerte énfasis en la condición colonial. Para ello, el autor recurrió a bibliografía del ámbito académico y del militante, y tomó datos, que le sirvieron para sustentar o ejemplificar sus tesis, de sus adversarios.

Otto Vargas postuló allí una historia desarrollada sobre la base del modo de producción como unidad que encerraba las potencialidades de ambas sociedades, americana y española. Allí explicó que los españoles lograron imponer el feudalismo por encontrarse en un estadio superior de desarrollo respecto a las sociedades americanas, aún los incas se encontraban transitando, para Vargas, la etapa primitiva de la sociedad esclavista. En ese contexto, el imperio incaico habría creado las condiciones necesarias, mediante la apropiación del plustrabajo campesino y artesano por parte de una "nobleza jerarquizada", para que el feudalismo español pueda desarrollarse a partir de él sin rupturas que hagan peligrar el dominio de la sociedad por una elite. Para el autor, la España que conquistó América era portadora de un feudalismo fortalecido producto de la reconquista peninsular del siglo $\mathrm{XV}$, lo que explicaría su rápida estructuración.

Este feudalismo trasladado a América, sobre la base de instituciones autóctonas, habría cambiado su ropaje, pero no su esencia. Vargas postuló que pese a la convivencia de determinadas formas de producción (esclavistas y comunitarias, por ejemplo) en la

65 Otto Vargas, Sobre el modo de producción dominante en el Virreinato del Rio de la Plata, Buenos Aires, Ágora, $1983,17$. 
época colonial ellas no pueden entenderse como dominantes, a lo sumo subsidiarias frente al predominio feudal. El autor, apoyándose en el historiador Francisco Chevalier, estudioso del régimen de la tierra y el trabajo en las haciendas en México durante el periodo colonial, sostuvo que la particularidad del feudalismo americano se encontró en la encomienda, que, como institución, a pesar de no ser ni un feudo, ni un señorío típico, no habría sido por ello menos feudal.

El texto se esforzó por demostrar que América Latina y Argentina se inscribían en el desarrollo histórico general de la humanidad. Las diferencias con los modelos de sociedad, esclavista, feudal o capitalista, fueron presentados por el autor como particularidades pero no como elementos que entraban en contradicción con un feudalismo original, impuesto, pero también autóctono. De esta forma en el territorio rioplatense la posesión de la tierra, que no era un feudo igual al español en la concepción de Vargas, fue hegemonizada por familias que la irán concentrando, a través de la expansión territorial e irán sujetando, mediante deudas y obligaciones, a las clases subalternas a su propiedad como mano de obra. Para Otto Vargas, las vaquerías y las estancias que se desarrollaron en el territorio rioplatense no habrían implicado, en lo más mínimo, un ensayo de desarrollo capitalista en los siglos XVIII y XIX. Este desarrollo se encontró trabado, según el autor, fundamentalmente, por la ausencia de un mercado de trabajo. El desarrollo capitalista será considerado como tardío, recién con la conquista del desierto, el alambrado de los campos, la inmigración y el código rural se solucionará, según Vargas, el problema de la mano de obra. El libro se cierra su argumentación apelando a la rebelión de Túpac Amaru como un hecho que en sí mismo desnudaría la naturaleza feudal de la sociedad colonial, su degeneración y sus contradicciones.

El ataque más directo al PC a lo largo del trabajo que formula Vargas está dirigido contra su dirigente rural José María García. Este es criticado en cuanto a que, según el dirigente maoísta, sostuvo en un escrito de 1945 que los hacendados, junto con los comerciantes porteños, se habrían ido convirtiendo en uno de los sectores más progresistas de la colonia, cuestión que finalmente los habría llevado a chocar con el dominio español en la década revolucionaria. Aquí, Vargas señaló que se encontraba un punto importante de las raíces de la desviación teórica del PCA en un partido revisionista y reformista. En otras palabras, Vargas ligó esta concepción histórica con el error de haber formado parte de la Unión Democrática y el posterior golpe de 1955 que derrocó a Perón. También se dirigió un fuerte ataque a Leonardo Paso, quien es calificado como el "conocido historiador del PC revisionista"66. De esta manera, se intentó romper con todo el legado historiográfico del partido que los había expulsado casi una década atrás.

En cuanto a la significación de esta producción podemos concluir señalando que, teniendo en cuenta su publicación en formato libro en 1983 y su reedición en 1985, sin alterar sustancialmente su contenido, quedaría evidenciado su carácter de respuesta oficial del PCR frente al problema del modo de producción dominante en el Río de la Plata. Su publicación previa, como folleto en 1977, luego del golpe, habría restringido su circulación a las esferas internas de la organización, cuestión subsanada con la salida del libro con el

66 Ibid, 176. 
retorno a la democracia. Sin embargo, debemos precisar que, en este caso, al tratarse de un debate hacia afuera, el PCR elaboró y puso a disposición del público su producción cuando los debates más resonantes de la época ya se habían producido. En el momento en que se publicó esta obra, el debate en cuestión ya había mutado en sus formas y contenido producto de la derrota política y teórica, consumada con el golpe de 1976, de toda una generación de militantes e intelectuales influenciados y formados en el marxismo.

\section{Consideraciones finales}

Como hemos expuesto a lo largo de este trabajo, reconocimos tres puertas de entrada a la Historia Argentina en la producción escrita del PCR: la historia de la izquierda, la cuestión agraria y el problema del modo de producción dominante. A lo largo del análisis hemos expuesto las formas que fueron tomando estos abordajes y su relación con la política partidaria. En el caso de la historia de la izquierda, hemos divisado que la modalidad con la que se trató el tema tomó la forma de un "ajuste de cuentas" con la historia previa. En relación con esto, hemos notado que este posicionamiento apuntó, en primer lugar, a justificar el nacimiento de la nueva organización en términos históricos y, en segundo término, a profundizar la distancia con la organización de la cual procedían. En lo que respecta al problema de la cuestión agraria hemos advertido que ella se revela como un tema/problema directamente relacionado con las discusiones programáticas al interior de la organización. Hemos evidenciado que estas resultaron relevantes a la hora de definir un plan de intervención en la lucha de clases y de definir el carácter de la revolución en el país. Por último, con respecto al modo de producción dominante en América Latina y la región rioplatense, hemos registrado una producción sostenida y polémica, pero, en este caso, hacia afuera de la organización: no hemos registrado la existencia de un debate interno al respecto. También en relación con este tercer tema, hemos dado cuenta de la modalidad que asumió para el PCR la tesis feudal de colonización y la continuidad que puede establecerse entre ella y la organización que expulsó a gran parte del núcleo fundador. Sin embargo, hemos detectado que esta problemática, las continuidades y rupturas de estas concepciones a las que hemos hecho referencia, ameritan un abordaje que dé cuenta de los matices entre ambas posiciones, cuestión que excede el presente escrito.

En este sentido, nuestro trabajo ha buscado plantear una serie de cuestiones que nos permitieran delimitar las problemáticas que, a nuestro parecer, merecen ser examinadas con mayor detenimiento. Cada una de las temáticas analizadas exige un análisis puntual que nos permita comprenderlas en todas sus dimensiones, contradicciones y desplazamientos.

A su vez, hemos detectado algunos elementos compartidos por estas intervenciones. En primer lugar, hemos considerado que se operaron en ellas una discusión y delimitación crecientes con las ideas del PC. Este movimiento se desarrolló desde las definiciones políticas y fue expresándose en todo un arco de temas y problemas que excedían la acción política inmediata. En segundo término, hemos detectado dos 
momentos y modos de apropiación de ideas y bibliografía por parte del PCR: una primera instancia, en la que el partido se valió de todo el material bibliográfico y teórico que encontró a su disposición, sin discriminar en cuanto a su procedencia, y un segundo momento en el que, de forma creciente, fue referenciando las ideas y las tesis más significativas de sus elaboraciones en las producciones propias y de sus intelectuales. Observamos que este proceso fue acompañado por la formación de una empresa editorial mediante la cual el partido fue publicando, en diversos formatos, las elaboraciones que expresaban sus posiciones oficiales. Estas posiciones, como pudimos observar a lo largo del artículo, fueron puestas en discusión y circulación dando lugar a una instancia creadora en materia de lectura histórica que cristalizó en los libros mencionados aparecidos en la década de 1980. Es decir, expusimos las formas en que estas elaboraciones fueron tomando forma en relación con los posicionamientos políticos.

En este trabajo analizamos un fenómeno que reúne dos aspectos: la historia política de la organización y sus lecturas del pasado histórico. Al considerar que estos dos aspectos configuran una unidad en nuestro análisis planteamos la necesidad de trabajar con la hipótesis de que las definiciones político-programáticas del partido se encontraron relacionadas directamente con sus formulaciones históricas, definiendo prioridades y núcleos conflictivos. Sin embargo, debemos precisar que esta relación presenta una doble dimensión. Por un lado, nos habilita a reconocer cierto perfil armónico entre la vida del partido y sus lecturas históricas y, por otro lado, nos abre el interrogante de la posibilidad de desajustes y reformulaciones que pueden haber tenido lugar a lo largo del tiempo. Profundizar estas últimas serán de vital importancia para conocer las condiciones de creación y formulación de un corpus historiográfico del PCR, los recorridos intelectuales de sus principales cuadros y sus acciones dentro de la estructura partidaria. Para ello, a diferencia de la perspectiva superficial adoptada en el presente escrito, es necesario abordar los núcleos problemáticos en profundidad. Si una foto nos permite ver las posiciones asumidas en un momento concreto, una película nos permitirá dar cuenta de los desplazamientos propios de una producción íntimamente atada al contexto.

\section{Bibliografía}

Acha, Omar, Historia critica de la historiografía argentina, Vol.1: Las izquierdas en el siglo XX, Prometeo, Buenos Aires, 2009

Andrade, Mariano, Para una historia del maoísmo argentino. Entrevista con Otto Vargas, Imago Mundi, Buenos Aires, 2007.

Brega Jorge, ¿Ha muerto el comunismo?, Buenos Aires, Ágora, 1990.

Campione, Daniel, Argentina la escritura de su Historia, Buenos Aires, Centro Cultural de la Cooperación, 2002.

Celentano, Adrian, "Insurrección y compromiso intelectual. Los Libros y Cristianismo y Revolución frente al Cordobazo y el Viborazo", en Archivos, año II, Nº 4, marzo de 2014, 5374 . 
Ciafardini, Horacio, "Feudalismo: economía y sociedad", en Los Libros, №37, Buenos Aires, septiembre-octubre 1974, 20-22.

Ciafardini, Horacio, "Capital, comercio y capitalismo: a propósito del llamado 'capitalismo comercial'", en: VV. AA., Modos de producción en América Latina, Cordoba, Cuadernos de Pasado y Presente, 1973, 111-134.

Crespo, Horacio, "En torno a los Cuadernos de Pasado y Presente, 1968-1983”, en El politico y el científico: Ensayos en homenaje a Juan Carlos Portantiero, editado por Claudia Hilb, Buenos Aires: Siglo XXI/UBA Facultad de Ciencias Sociales, 2009, s/p.

Devoto, Fernando, Pagano, Nora y Hourcade, Eduardo, La historiografía académica y la historiografía militante en Argentina y Uruguay, Buenos Aires, Biblos, 2004.

Devoto, Fernando y Pagano, Nora, Historia de la Historiografía Argentina, Sudamericana, Buenos Aires, 2009

Galban, Roque, "Acerca del problema agrario en nuestro país", en: Teoría y Política n4, Buenos Aires, año III, 1971, pp. 31-50.

Gastiazoro, Eugenio, Historia argentina. Introducción al análisis económico/social. Tomo I (15151820), Buenos Aires: Ágora, 1986.

Gastiazoro, Eugenio, Historia Argentina. Introducción al análisis económico/social, Tomo III (1880-1930), Ágora, Buenos Aires, 1986.

Gastiazoro, Eugenio, Historia Argentina. Introducción al análisis económico/social, Tomo II (1820-1880), Ágora, Buenos Aires, 1986.

Gilbert Isidoro, La FEDE. Alistándose para la revolución. La Federación Juvenil Comunista 19212005, Buenos Aires, Sudamericana, 2009.

Irusta, Rosendo, Sobre el modo de producción dominante en el virreinato del Rio e la Plata, Buenos Aires, Ediciones de Mayo, 1977. Irusta, Rosendo, "Sobre el modo de producción dominante en el Virreinato del Rio de la Plata”, en Teoría y Política, n¹7, año VII, 1976, 9-19.

Irusta, Rosendo, "Sobre el modo de producción dominante en el Virreinato del Rio de la Plata ( $2^{\circ}$ Parte)", en Teoría y Política, n¹8, año VIII, 1977, 4-50.

Kossok, Manfred, "Feudalismo y capitalismo en la historia de América Latina”, en Los Libros, N³7, Buenos Aires, septiembre-octubre 1974, 13-19.

Marín, Andrés, "Argentina 1880-1914. Notas sobre capitalismo, prusianismo y dependencia”, en Teoría y Política n² 2, año I, Buenos Aires, 1969, 93-115.

Marín, Andrés y Figarí, Lucas, "El método para analizar la lucha de clases en el campo", en Teoría y Política n6, año III, 1971, 49-56.

Lissandrelo, Guido. “La discusión estratégica en la izquierda argentina en los años '70: Aproximación al debate entre guerrillerismo e insurreccionalismo en el Partido Comunista Revolucionario (PCR), 1967-1972" en Andes [online]. 2015, vol.26, n.1, 00-00.

Pacheco, Julieta, Nacional y Popular. El MALENA y la construcción del programa de liberación nacional (1955-1969), Buenos Aires, ryr, 2012.

Páez, Hugo, “Teoría de la dependencia: inútil contra el viejo amo, útil para el nuevo”, en Teoría y Política n¹4, año VI, 1975, 14-23.

Páez, Hugo "Sobre algunos enfoques unilaterales de la historia", en Teoría y Política, n¹7, año VII, 1976, 20-23. 
Ratzer, José, Los marxistas argentinos del 90, Córdoba, Ediciones Pasado y Presente, 1970. Ratzer, José, El movimiento socialista en Argentina, Buenos Aires, Ediciones Ágora, 1981. Rupar, Brenda (2018), “El Partido Comunista Revolucionario: de su ruptura con el Partido Comunista Argentino a su adopción del maoísmo (1967-1974)", en Brice Calsapeu Losfeld y Miguel Ángel Urrego Ardilla (Coord.), La década roja (1966-1976), IIH/UMSNH, Morelia, 2018 [en publicación]

Rupar, Brenda, “El rol de la revolución cultural china en el maoísmo argentino. Las interpretaciones en las visiones oficiales de Vanguardia Comunista y el Partido Comunista Revolucionario", en Leste Vermelho. Revista de Estudos Críticos Asiáticos, Año: 2017, vol. 3, $355-375$

Rupar, Brenda, “Vía pacífica ou vía armada: os debates na esquerda revolucionária na década de 1960, através de duas organizações maoístas argentinas", en História; Año 2016, vol. 1, 6 - 24

Sánchez, Pilar, El gordo Antonio. Vida, pasión y asesinato del dirigente comunista revolucionario Cesar Godoy Álvarez, Buenos Aires, Ágora, 2008.

Serdán, Pedro (1971), “Acerca de la clase obrera rural (en una parte de la pampa húmeda)", en: Teoría y Política n5, año III, 27-35.

Stella Grenat, Una espada sin cabeza. Las FAL y la construcción de un partido revolucionario en los '70, Buenos Aires, ediciones ryr, 2011;

Tarcus, Horacio (1996), El marxismo olvidado en la Argentina: Silvio Frondizi y Milciades Peña, Ediciones El Cielo por Asalto, Buenos Aires.

Vargas, Otto, Sobre el modo de producción dominante en el Virreinato del Rio de la Plata, Buenos Aires, Editorial Ágora, 1983.

Vargas, Otto, El marxismo y la revolución argentina, Buenos Aires, Ágora, 1987.

Vargas, Otto, Los Ignorados, Buenos Aires, Cuadernos de Ágora II, 1992

Vargas, Otto, El marxismo y la revolución argentina, Tomo II, Buenos Aires, Ágora, 1999.

\section{Fuentes y documentos}

Revista Los Libros, 1974

Revista Teoría y Politica, 1969-1977

PCR, Documentos aprobados desde la ruptura con el PC revisionista hasta el $1^{a}$ Congreso del PCR 1967/1969, PCR, Buenos Aires, 2003.

PCR, Documentos aprobados por el PCR a partir de su $1^{\circ}$ Congreso, diciembre de 1969, hasta su $2^{\circ}$ congreso, abril de 1972, Publicaciones 35 aniversario, Buenos Aires, 2005.

PCR, Documentos aprobados por el PCR a partir de su $2^{\circ}$ Congreso, abril de 1972, hasta su $3^{\circ}$

Congreso, marzo de 1974, Publicaciones 35 aniversario del PCR, 2005.

PCR, Documentos aprobados por el PCR a partir de su $3^{\circ}$ Congreso, marzo de 1974, hasta su $4^{\circ}$

Congreso, abril de 1984 (Primera parte 1974-1979), Tomo 4, Publicaciones 35ªniversario del

PCR, Buenos Aires, 2006.

PCR, Documentos aprobados por el PCR a partir de su $3^{\circ}$ Congreso, marzo de 1974, hasta su $4^{\circ}$ Congreso, abril de 1984 (Segunda parte 1980-1984), Tomo 4, Publicaciones 35ªniversario del PCR, Buenos Aires, 2007.

Entrevista

Entrevista a Eugenio Gastiazoro, realizada por el autor en abril de 2018. 